\title{
Correlations among Predawn Leaf, Midday Leaf, and Midday Stem Water Potential and their Correlations with other Measures of Soil and Plant Water Status in Vitis vinifera
}

\author{
L.E. Williams ${ }^{1}$ and F.J. Araujo ${ }^{2}$ \\ Department of Viticulture and Enology, University of California, 1 Shields Ave., Davis, CA 95616
}

AdDitional INDEX WORDs. grapevines, photosynthesis, stomatal conductance, plant water status

\begin{abstract}
A study was conducted to compare three measurements of determining water status of grapevines (Vitis vinifera $\mathrm{L}_{\text {. }}$ ) in the field. Predawn leaf water potential $\left(\Psi_{\mathrm{PD}}\right)$, midday leaf water potential $\left(\Psi_{\mathrm{I}}\right)$, and midday stem water potential $\left(\Psi_{\text {stem }}\right)$ were measured on 'Chardonnay' and 'Cabernet Sauvignon' grapevines grown in Napa Valley, California late in the 1999 growing season. Both cultivars had been irrigated weekly at various fractions $(0,0.5$, and 1.0 for 'Chardonnay' and $0,0.5,0.75$, and 1.5 for 'Cabernet') of estimated vineyard evapotranspiration ( $\left.E T_{c}\right)$ from approximately anthesis up to the dates of measurements. Predawn water potential measurements were taken beginning at $0330 \mathrm{HR}$ and completed before sunrise. Midday $\Psi_{1}$ and $\Psi_{\text {stem }}$ measurements were taken only between 1230 and $1330 \mathrm{HR}$. In addition, net $\mathrm{CO}_{2}$ assimilation rates $(\mathrm{A})$ and stomatal conductance to water vapor $\left(\mathrm{g}_{\mathrm{s}}\right)$ were also measured at midday. Soil water content (SWC) was measured in the 'Chardonnay' vineyard using a neutron probe. Values obtained for $\Psi_{\mathrm{PD}}$, $\Psi_{1}$, and $\Psi_{\text {stem }}$ in this study ranged from about -0.05 to $-0.8,-0.7$ to -1.8 , and -0.5 to $-1.6 \mathrm{MPa}$, respectively. All three measurements of vine water status were highly correlated with one another. Linear regression analysis of $\Psi_{1}$ and $\Psi_{\text {stem }}$ versus $\Psi_{\mathrm{PD}}$ resulted in $r^{2}$ values of 0.88 and 0.85 , respectively. A similar analysis of $\Psi_{1}$ as a function of $\Psi_{\text {stem }}$ resulted in an $r^{2}$ of 0.92. In the 'Chardonnay' vineyard, all three methods of estimating vine water status were significantly $(P<0.01)$ correlated with SWC and applied amounts of water. Lastly, $\Psi_{\mathrm{PD}}, \Psi_{1}$, and $\Psi_{\text {stem }}$ were all linearly correlated with measurements of $A$ and $g_{s}$ at midday. Under the conditions of this study, $\Psi_{\mathrm{PD}}, \Psi_{\mathrm{l}}$, and $\Psi_{\text {stem }}$ represent equally viable methods of assessing the water status of these grapevines. They were all correlated similarly with the amount of water in the soil profile and leaf gas exchange as well as with one another.
\end{abstract}

Since development of the pressure chamber (Scholander et al., $1965)$, measurement of leaf water potential $\left(\Psi_{1}\right)$ has been used as a tool to assess the water status of plants (Jones, 1990; Koide et al., 1989). Accordingly, leaf $\Psi_{1}$ has been used to monitor the water relations of grapevines (Vitis L. sp.) (Smart and Coombe, 1982; Williams et al., 1994). It has been correlated with various aspects of grapevine physiology (Naor et al., 1994; Williams et al., 1994), vegetative growth (Schultz and Matthews, 1988, 1993), and reproductive growth and yield (Greenspan et al., 1996; Grimes and Williams, 1990). Grapevine $\Psi_{1}$ has been shown to be fairly consistent up and down the axis of the shoot of Vitis labruscana Bailey when leaves are uniformly exposed to solar radiation (Liu et al., 1978). Lastly, $\Psi_{1}$ has also been used as a factor in a functional model of stomatal conductance of grapevines (Winkel and Rambal, 1990).

There have been reports in which it was suggested that midday or diurnal measurements of $\Psi_{1}$ did not provide a reliable estimate of plant water status. This was due to lack of correlation between $\Psi_{1}$ with other physiological parameters, measures of growth, or amounts of applied water (Chone et al., 2001; Garnier and Berger, 1985; Higgs and Jones, 1990; Naor, 1998). Therefore, other methods of measuring plant water status in the field, such as predawn leaf water potential $\left(\Psi_{\mathrm{PD}}\right)$ and stem water potential $\left(\Psi_{\text {stem }}\right)$ are being used. Measurements of $\Psi_{\mathrm{PD}}$ have been used in grape studies since it is assumed that before sunrise the vine is in equilibrium with the soil's water potential (Correia et al., 1995; Schultz, 1996; Winkel and Rambal, 1993). Correia et al. (1995) found significant differences in

Received for publication 25 May 2001. Accepted for publication 1 Jan. 2002. ${ }^{1}$ Corresponding author; University of California, Kearney Agricultural Center, 9240 S. Riverbend Ave., Parlier, CA 93648; e-mail Williams@uckac.edu.

${ }^{2}$ Visiting scientist; Facultad de Agronomia, Universidad del Zulia. Nucleo Agropecuario, Av. Goajira, Maracaibo 4001, Estado Zulia, Venezuela. vine $\mathrm{Y}_{\mathrm{PD}}$ among three watering treatments but no differences in $\Psi_{1}$ were found when measured at 1000 and $1600 \mathrm{HR}$. They concluded that $\Psi_{\mathrm{PD}}$ better reflected soil water availability than $\Psi_{1}$. van Zyl (1987) concluded that $\Psi_{P D}$ detected the onset of water stress in grapevines earlier and more accurately than $\Psi_{1}$.

Stem water potential is determined by enclosing a leaf in a plastic bag that is surrounded by aluminum foil, stopping transpiration, enabling that leaf to come into equilibrium with the water potential of the stem (Begg and Turner, 1970). The reported amount of time between enclosing the leaf in plastic and foil, and measuring $\Psi_{\text {stem }}$ for trees and grapevines, has been from 45 to $120 \mathrm{~min}$ (Garnier and Berger, 1987; McCutchan and Shackel, 1992; Naor et al., 1997). Some have bagged leaves from 14 to $24 \mathrm{~h}$ before measuring $\Psi_{\text {stem }}$ in grape (Liu et al., 1978; Stevens et al., 1995). Stem water potential has been shown to be less variable than $\Psi_{1}$ and improved the ability to detect small, but statistically significant differences among treatments (McCutchan and Shackel, 1992). It was also found that a clear difference in $\Psi_{\text {stem }}$ between two irrigation treatments occurred at an earlier date (1 week) during the growing season than differences in $\Psi_{\mathrm{PD}}$ and $\Psi_{1}$ for the same treatments (Selles and Berger, 1990). In addition, $\Psi_{\text {stem }}$ has been shown to be a linear function of applied water (Lampinen et al., 1995) and soil water availability (Stevens et al., 1995). Lastly, $\Psi_{\text {stem }}$ has been highly correlated with tree (Olien and Lakso, 1986) and fruit (Naor et al., 1995) size in apple [Malus sylvestris (L.) Mill var. domestica (Borkh.) Mansf.].

It has been suggested that for a measure of plant water status (such as $\Psi_{1}$ ) to be a sensitive indicator of water stress, it must be responsive to differences in soil moisture status and/or resulting growth differences due to water applications (Higgs and Jones, 1990). It should also be closely related to short- and medium-term plant stress responses (Shackel et al., 1997) and less dependent upon changes in environmental conditions (Jones, 1990; 
McCutchan and Shackel, 1992). The specific examples given above for grape would indicate that $\Psi_{\mathrm{PD}}, \Psi_{1}$, or $\Psi_{\text {stem }}$ may all be possible candidates. Only a few studies have actually compared one of the three methods of measuring $\Psi$ with one another for determination of plant water status. Stevens et al. (1995) found that diurnal measures of $\Psi_{1}$ and $\Psi_{\text {stem }}$ of grape were highly correlated $\left(r^{2}=0.97\right)$ with one another. Conversely, Naor et al. (1995) found that the correlation between $\Psi_{1}$ and $\Psi_{\text {stem }}$ of apple resulted in a $r^{2}$ of 0.35 . Therefore, the purpose of this study was to measure $\Psi_{\mathrm{PD}}, \Psi_{1}$, and $\Psi_{\text {stem }}$ of two Vitis vinifera cultivars and compare the three with one another and with measures of leaf gas exchange, soil water content, and reproductive growth. Grapevines at two sites were chosen as they had been irrigated at various fractions of estimated vineyard evapotranspiration $\left(\mathrm{ET}_{\mathrm{c}}\right)$ from the initial irrigation of the season onward, providing plant material expected to exhibit large differences in soil and vine water status.

\section{Materials and Methods}

Two Vitis vinifera cultivars were used for the study, 'Chardonnay' and 'Cabernet Sauvignon'. The 9-year-old 'Chardonnay' vineyard was located in the southern portion of Napa Valley (Carneros District), in California within $10 \mathrm{~km}$ of San Francisco Bay. The 10year-old 'Cabernet Sauvignon' vineyard was also located in Napa Valley, $3 \mathrm{~km}$ from Oakville ( $\approx 25 \mathrm{~km}$ from the Carneros site). Two rootstocks were used in the 'Chardonnay' vineyard, '5C Teleki' (5C) and '110 Richter' (110R). One rootstock was used in the 'Cabernet Sauvignon' vineyard, 5C. Vine and row spacings for the 'Chardonnay' and 'Cabernet Sauvignon' vineyards were 1.52 and $2.13 \mathrm{~m}$ and 1.0 and $1.83 \mathrm{~m}$, respectively. The trellis system used in both vineyards was the vertical shoot positioned (VSP). Row directions in the 'Chardonnay' and 'Cabernet Sauvignon' vineyards were approximately east-west and north-south, respectively. The soil in the 'Chardonnay' vineyard was a Diablo fine, montmorillonitic, thermic Chromic Pelloxerert and that in the 'Cabernet' vineyard was a Bale fine-loamy, mixed, thermic Cumulic Ultic Haploxeroll. The soil $\mathrm{pH}$ of both vineyards was 5.5 and there were no apparent restrictions to root exploration of the profile.

Both vineyards used for this research were also being used in an irrigation study investigating relationships among applied quantities of water, rootstock, and productivity. Three irrigation treatments were used in the 'Chardonnay' vineyard. Vines received applied amounts of water at $0,0.5$, and 1.0 times estimated $\mathrm{ET}_{\mathrm{c}}$. The plot size of an individual irrigation-rootstock treatment consisted of 18 vines down the row using a single border vine and a border row receiving no applied water between plots. Vine water use was calculated as the product of potential ET $\left(\mathrm{ET}_{\mathrm{o}}\right)$ and the crop coefficient $\left(\mathrm{k}_{\mathrm{c}}\right)$. Potential ET was obtained from a California Irrigation Management Irrigation System (CIMIS) weather station located $8 \mathrm{~km}$ from the vineyard site. The seasonal crop coefficients $\left(\mathrm{k}_{\mathrm{c}} \mathrm{s}\right)$ used were those developed by L.E. Williams in 1994 for a VSP trellis planted on 2.13-m row spacings (unpublished data) and expressed as a function of degree-days from budbreak using a base of $10{ }^{\circ} \mathrm{C}$. Four irrigation treatments were used in the 'Cabernet Sauvignon' vineyard: $0.0,0.5,0.75$, and 1.5 times estimated $\mathrm{ET}_{\mathrm{c}}$. The plot size of an irrigation treatment at this location was the entire row (78 vines). The $\mathrm{k}_{\mathrm{c}} \mathrm{s}$ used to calculate $\mathrm{ET}_{\mathrm{c}}$ were similar to those in the 'Chardonnay' vineyard but were adjusted for the narrower row spacing (i.e., the $\mathrm{k}_{\mathrm{c}} \mathrm{s}$ were $\approx 16 \%$ greater than for the $2.13 \mathrm{~m}$ row spacing). Potential ET for the 'Cabernet' vineyard was obtained from a CIMIS weather station located $3 \mathrm{~km}$ from the site. Differences in applied water amounts in both vineyards were obtained by using different numbers and/or sizes of in-row emitters using drip irrigation.

Soil water content (SWC) was measured only in the 'Chardonnay' vineyard using a neutron probe (model 503 DR hydroprobe moisture gauge; Boart Longyear Co., Martinez, Calif.). Six access tubes were installed to a depth of $3 \mathrm{~m}$ in one quarter of an individual vine's rooting volume. One tube was placed close to the trunk of the vine and another midway between vines within the row. Two access tubes were placed midway between rows, in line (perpendicular) with the two in-row tubes. The last two access tubes were placed midway between the four tubes, mentioned previously (i.e., 1/4 the distance between rows). There was one access tube site per irrigation treatment-rootstock combination. Measurements of SWC began at a depth of $0.15 \mathrm{~m}$ from the soil surface and at each $0.3-\mathrm{m}$ depth, thereafter. The neutron probe was calibrated with the vineyard's soil type and expressed as percentage volumetric water content. Soil water content used in the study was the mean of all access tubes at an individual site and at all depths measured.

Vine water status and leaf gas exchange were measured on two dates (24 Aug. and 21 Sept. 1999) in the 'Chardonnay' vineyard and one date (25 Aug. 1999) in the 'Cabernet' vineyard on randomly selected vines only in block 1 of the larger irrigation study at both locations. Soil water content was also measured only in block 1 of the 'Chardonnay' vineyard both days. All dates were cloud free. Water potential readings were conducted according to the procedures of Padgett-Johnson et al. (2000) and Koide et al. (1989). Specifically, predawn $\Psi$ measurements began at $\approx 0330 \mathrm{HR}$ and were finished before sunrise using a pressure chamber (PMS Instruments Co., Corvallis, Ore.). Midday measurements of $\Psi_{1}$ and $\Psi_{\text {stem }}$ occurred between 1230 and 1330 HR, Pacific Daylight Time. Leaf blades for $\Psi_{\mathrm{PD}}$ and $\Psi_{1}$ determinations were covered with a plastic bag, quickly sealed, and petioles then cut within 1 to $2 \mathrm{~s}$. The time between leaf excision and chamber pressurization was generally $<10$ to $15 \mathrm{~s}$. Leaves, chosen for midday $\Psi_{1}$ determinations, were fully expanded, mature leaves exposed to direct solar radiation. These leaves were located on the south side of east-west rows and the west side of the north-south rows. About 90 to 120 min before midday measurements, leaves for determination of $\Psi_{\text {stem }}$ were enclosed in black plastic bags covered with aluminum foil. Leaves chosen for $\Psi_{\text {stem }}$ measurements were of similar age and type as those used for $\Psi_{1}$ but were located on the north side of the vines in eastwest rows and the east side of vines in north-south rows to minimize any possible heating effects. Leaves for midday determinations of $\Psi_{1}$ and $\Psi_{\text {stem }}$ were taken from the same vine and simultaneously measured. One leaf from an individual vine was used for each measurement.

In Aug. 2001, midday $\Psi_{1}$ was measured on the cultivar Merlot grown in the San Joaquin Valley, comparing leaves covered with a plastic bag before excision, covered with a plastic bag just after excision, and leaves not covered with plastic. All other procedures were as described above for midday $\Psi_{1}$. A single leaf replication of each method to measure $\Psi_{1}$ was taken from the same vine using six different vines. Vines were irrigated at $40 \%$ and $120 \%$ of estimated vineyard ET, weekly.

Measurements of net $\mathrm{CO}_{2}$ assimilation rates (A) and stomatal conductance $\left(\mathrm{g}_{\mathrm{s}}\right)$ were taken subsequent to the measurements of midday leaf $\Psi$ and completed by $1400 \mathrm{HR}$. Both measures of gas exchange were made with a portable infrared gas analyzer, LCA2 (Analytical Development Co., Hoddeson, United Kingdom) using the broad leaf chamber. Leaves chosen for gas exchange were similar to those used for $\Psi_{1}$. Solar radiation, net radiation, photosynthetic photon flux $(P P F)$, ambient temperature and, relative humid- 
Table 1. Effects of applied water amounts on predawn leaf $\left(\Psi_{\mathrm{PD}}\right)$, midday stem $\left(\Psi_{\text {stem }}\right)$, and midday leaf $\left(\Psi_{1}\right)$ water potentials for selected grape

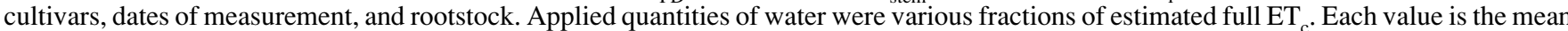
of a single leaf replicate measured on six different vines for data collected on 24 Aug. and five different vines for the other two measurement dates.

\begin{tabular}{|c|c|c|c|c|c|c|}
\hline \multirow[b]{2}{*}{ Cultivar } & \multirow[b]{2}{*}{ Date } & \multirow[b]{2}{*}{ Rootstock } & \multirow{2}{*}{$\begin{array}{c}\text { Applied water } \\
\text { (fraction of } \mathrm{ET}_{\mathrm{c}} \text { ) }\end{array}$} & $\Psi_{\mathrm{PD}}$ & $\Psi_{\text {stem }}$ & $\Psi_{1}$ \\
\hline & & & & \multicolumn{3}{|c|}{$\mathrm{MPa}$} \\
\hline \multirow[t]{6}{*}{ 'Chardonnay' } & 24 Aug. & $5 \mathrm{C}$ & 0.0 & $-0.45 \mathrm{c}^{\mathrm{z}}$ & $-1.17 \mathrm{c}$ & $-1.50 \mathrm{c}$ \\
\hline & & & 0.5 & $-0.16 \mathrm{~b}$ & $-0.92 b$ & $-1.25 \mathrm{~b}$ \\
\hline & & & 1.0 & $-0.10 \mathrm{a}$ & $-0.74 \mathrm{a}$ & $-1.04 \mathrm{a}$ \\
\hline & & $110 \mathrm{R}$ & 0.0 & $-0.60 \mathrm{c}$ & $-1.44 \mathrm{~b}$ & $-1.64 \mathrm{~b}$ \\
\hline & & & 0.5 & $-0.24 \mathrm{~b}$ & $-0.98 \mathrm{a}$ & $-1.28 \mathrm{a}$ \\
\hline & & & 1.0 & $-0.14 \mathrm{a}$ & $-0.86 \mathrm{a}$ & $-1.13 \mathrm{a}$ \\
\hline \multirow[t]{6}{*}{ 'Chardonnay' } & 21 Sept. & $5 \mathrm{C}$ & 0.0 & $-0.46 \mathrm{~b}$ & $-1.29 b$ & $-1.54 b$ \\
\hline & & & 0.5 & $-0.05 \mathrm{a}$ & $-0.82 \mathrm{a}$ & $-1.06 \mathrm{a}$ \\
\hline & & & 1.0 & $-0.02 \mathrm{a}$ & $-0.72 \mathrm{a}$ & $-1.02 \mathrm{a}$ \\
\hline & & $110 \mathrm{R}$ & 0.0 & $-0.62 \mathrm{~b}$ & $-1.64 \mathrm{c}$ & $-1.81 \mathrm{c}$ \\
\hline & & & 0.5 & $-0.06 \mathrm{a}$ & $-0.69 b$ & $-0.98 \mathrm{~b}$ \\
\hline & & & 1.0 & $-0.02 \mathrm{a}$ & $-0.60 \mathrm{a}$ & $-0.86 \mathrm{a}$ \\
\hline \multirow[t]{4}{*}{ Cabernet } & 25 Aug. & $5 \mathrm{C}$ & 0.0 & $-0.75 \mathrm{c}$ & $-1.39 \mathrm{c}$ & $-1.71 \mathrm{c}$ \\
\hline & & & 0.5 & $-0.57 \mathrm{~b}$ & $-1.11 \mathrm{~b}$ & $-1.37 \mathrm{~b}$ \\
\hline & & & 0.75 & $-0.51 \mathrm{~b}$ & $-1.11 b$ & $-1.39 b$ \\
\hline & & & 1.5 & $-0.26 \mathrm{a}$ & $-0.96 \mathrm{a}$ & $-1.29 \mathrm{a}$ \\
\hline
\end{tabular}

${ }^{\mathrm{z}}$ Means within a column followed by a different letter for a specific cultivar, date and rootstock are significantly different at $P<0.05$.

ity were measured $1 \mathrm{~m}$ above the canopy and averaged hourly with a datalogger. Canopy temperature (to calculate canopy to air vapor pressure difference) was measured hourly with a hand-held infrared thermometer (model 39650-04; Cole-Parmer Inst. Co., Chicago, Ill.).

Data were analyzed via regression analysis using linear, quadratic, and cubic terms. Since there were no improvements using either quadratic or cubic terms for analysis of any of the relationships obtained herein only linear regressions are presented. The relationships between midday measurements $\left(\Psi_{1}\right.$ and $\left.\Psi_{\text {stem }}\right)$ and $\Psi_{\mathrm{PD}}$ were analyzed using the means of an individual treatment (scionrootstock combination, irrigation treatment, and date, $n=16$ ). This was due to the fact that measurement of $\Psi_{\mathrm{PD}}$ was not necessarily determined on the same vines within the plot as done for $\Psi_{1}$ and $\Psi_{\text {stem }}$. The relationship between $\Psi_{1}$ and $\Psi_{\text {stem }}$ was of individual leaf replicates ( $\mathrm{n}=6$ for each scion-rootstock combination, irrigation treatment in the 'Chardonnay' vineyard on 24 Aug. while $n=5$ for each treatment in the 'Chardonnay' vineyard measured on 21 Sept. and for the 'Cabernet Sauvignon' vines measured on 25 Aug.; total $\mathrm{n}=86$ ). The relationships between $\mathrm{A}$ and $\mathrm{g}_{\mathrm{s}}$ and water potentials were also determined using treatment means as $\mathrm{A}$ and $\mathrm{g}_{\mathrm{s}}$ were not necessarily determined on the same leaves and/or vines as $\Psi$ measurements were within block 1 at each location. Differences in water potential among irrigation treatments at either site were analyzed via analysis of variance and means separated using Duncan's multiple range test. An analysis of covariance was used to test for heterogeneity of slopes for the relationship between $\Psi_{\text {stem }}$ and $\Psi_{1}$ among the three different measurement dates.

\section{Results}

There had been no significant rainfall since anthesis at either site in 1999. Irrigations commenced at both locations in the middle of June and water was applied once per week. The 'Chardonnay' vines had been irrigated $5 \mathrm{~d}$ before measurements of vine water status in August, while in September the vines were irrigated the previous day. Potential ET the weeks of 23 Aug. and 20 Sept. at the Carneros
CIMIS station (used for calculating $\mathrm{ET}_{\mathrm{c}}$ for the 'Chardonnay' vineyard) was 30.7 and $21.9 \mathrm{~mm}$, respectively. Applied amounts of water at $100 \%$ of $\mathrm{ET}_{\mathrm{c}}$ in the 'Chardonnay' vineyard the week measurements were taken were $63.8 \mathrm{~L} /$ vine $(19.7 \mathrm{~mm})$ in August and 49.6 L/vine $(15.3 \mathrm{~mm})$ in September. Ambient temperatures and canopy to air vapor pressure difference at the time of the midday measurements in the 'Chardonnay' vineyard were $26^{\circ} \mathrm{C}$ and $2.5 \mathrm{kPa}$ in August and $27^{\circ} \mathrm{C}$ and $1.9 \mathrm{kPa}$, in September, respectively. PPF measured in the 'Chardonnay' vineyard was in excess of 1,700 $\mathrm{mmol} \cdot \mathrm{m}^{-2} \cdot \mathrm{s}^{-1}$ at solar noon. It should be pointed out that the irrigation pump in the 'Cabernet' vineyard broke 2 weeks before 25 Aug. 1999, and it had not been fixed on the date measurements were

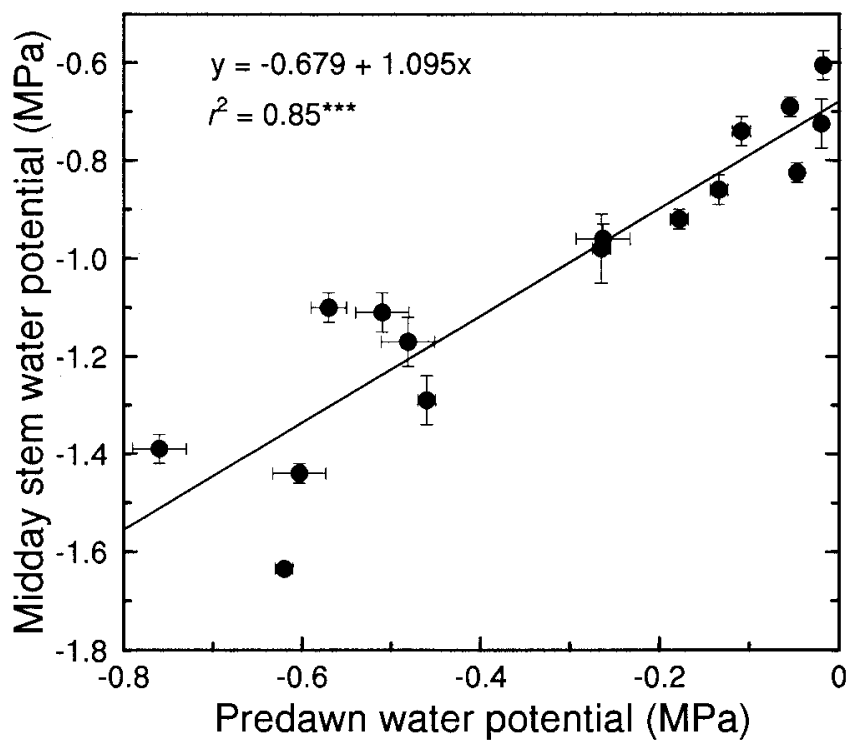

Fig. 1. Relationship between midday stem water potential $\left(\Psi_{\text {stem }}\right)$ and predawn leaf water potential $\left(\Psi_{\mathrm{PD}}\right)$ of 'Chardonnay' and 'Cabernet Sauvignon' grapevines. An individual data point is the mean of either five or six individual leaf replicates (See Materials and Methods). Bars larger than the symbols represent \pm 1 SE. ${ }^{* * * *}$ Significant at $P<0.001$. 


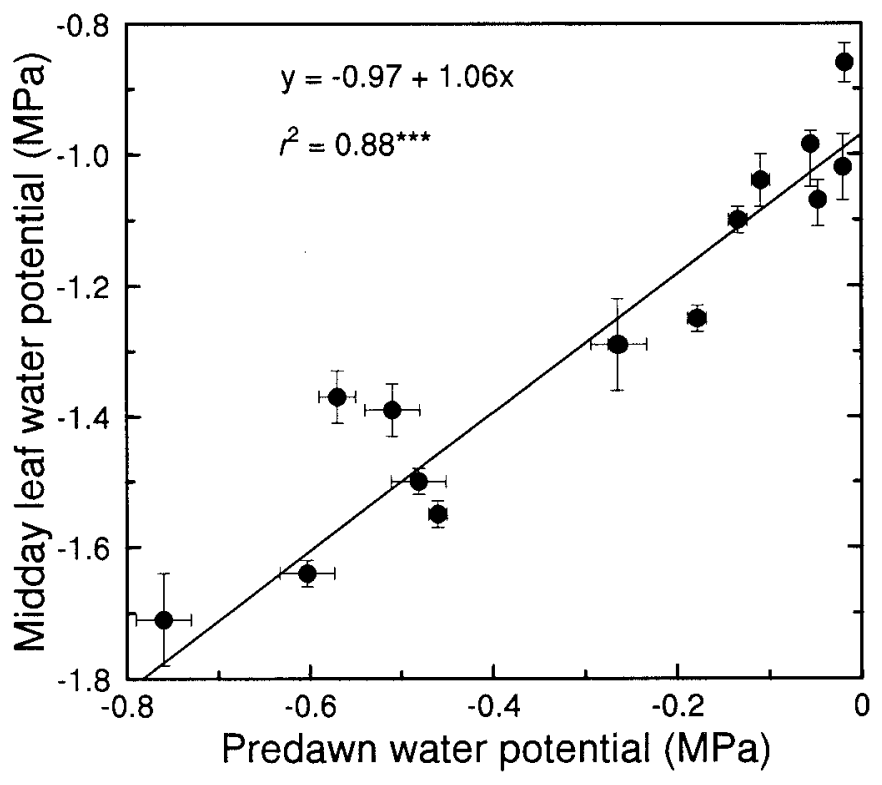

Fig. 2. Relationship between midday leaf water potential $\left(Y_{1}\right)$ and predawn leaf water potential for the vines used in the study. See Fig. 1 for additional information. ${ }^{* * *}$ Significant at $P<0.001$.

taken. Ambient temperature at midday on 25 Aug. was $36.7{ }^{\circ} \mathrm{C}$ (maximum temperature that day was $41.3^{\circ} \mathrm{C}$ ) and midday canopy to air vapor pressure difference was almost $5.0 \mathrm{kPa}$ (maximum that day was $7.4 \mathrm{kPa}$ ). The $P P F$ at $1300 \mathrm{HR}$ was $1679 \mathrm{mmol} \cdot \mathrm{m}^{-2} \cdot \mathrm{s}^{-1}$ on 25 Aug.

Use of irrigation treatments at both locations resulted in a wide range of vine water statuses (Table 1). The lowest values of $\Psi_{\mathrm{PD}}, \Psi_{1}$, and $\Psi_{\text {stem }}$ recorded for an individual leaf were $-0.85,-1.85$, and $-1.65 \mathrm{MPa}$, respectively. The highest values of $\Psi_{\mathrm{PD}}, \Psi_{1}$, and $\Psi_{\text {stem }}$ recorded for an individual leaf were $-0.02,-0.75$, and $-0.55 \mathrm{MPa}$, respectively. In most cases, significant differences among irrigation treatments for one measure of vine water status were also similarly different for the other two (Table 1). The exceptions were for the $110 \mathrm{R}$ rootstock measured on both dates. On 24 Aug. $\Psi_{\mathrm{PD}}$ was significantly different between the 0.5 and 1.0 irrigation treatments but $\Psi_{\text {stem }}$ and $\Psi_{1}$ were not. On 21 Sept., $\Psi_{\text {PD }}$ between the 0.5 and 1.0 irrigation treatments was not significantly different, but $\Psi_{\text {stem }}$ and $\Psi_{1}$ were.

All three methods of estimating vine water status were highly correlated with one another (Figs. 1-3). The best correlation was between midday $\Psi_{1}$ and $\Psi_{\text {stem }}$ (Fig. 3). All three methods of estimating vine water status were also significantly correlated with SWC in the 'Chardonnay' vineyard (Table 2).

Maximum and minimum values of $\mathrm{A}$ in terms of $\mathrm{CO}_{2}$ for an individual leaf measured at either location were 13.5 and 1.7 $\mathrm{mmol} \cdot \mathrm{m}^{-2} \cdot \mathrm{s}^{-1}$, respectively. Maximum and minimum values of $\mathrm{g}_{\mathrm{s}}$

Table 2. Regression equations of the method of measuring vine water status as a function of soil water content and the coefficient of determination and its significance level of 'Chardonnay' grapevines. Regressions are based on mean values of all measures of water potential. Soil water content was expressed as $\% \mathrm{vol} / \mathrm{vol}$ and water potential in $\mathrm{MPa}$.

\begin{tabular}{llc}
\hline \hline$\Psi$ measurement & Regression & $r^{2}$ \\
\hline Predawn leaf $\left(\Psi_{\mathrm{PD}}\right)$ & $\mathrm{y}=-3.81+0.099 \mathrm{x}$ & $0.69^{* *}$ \\
Midday leaf $\left(\Psi_{1}\right)$ & $\mathrm{y}=-5.86+0.129 \mathrm{x}$ & $0.68^{* *}$ \\
Midday stem $\left(\Psi_{\text {stem }}\right)$ & $\mathrm{y}=-5.77+0.134 \mathrm{x}$ & $0.63^{* *}$ \\
\hline
\end{tabular}

\footnotetext{
${ }^{* *}$ Significant at $P<0.01$.
}

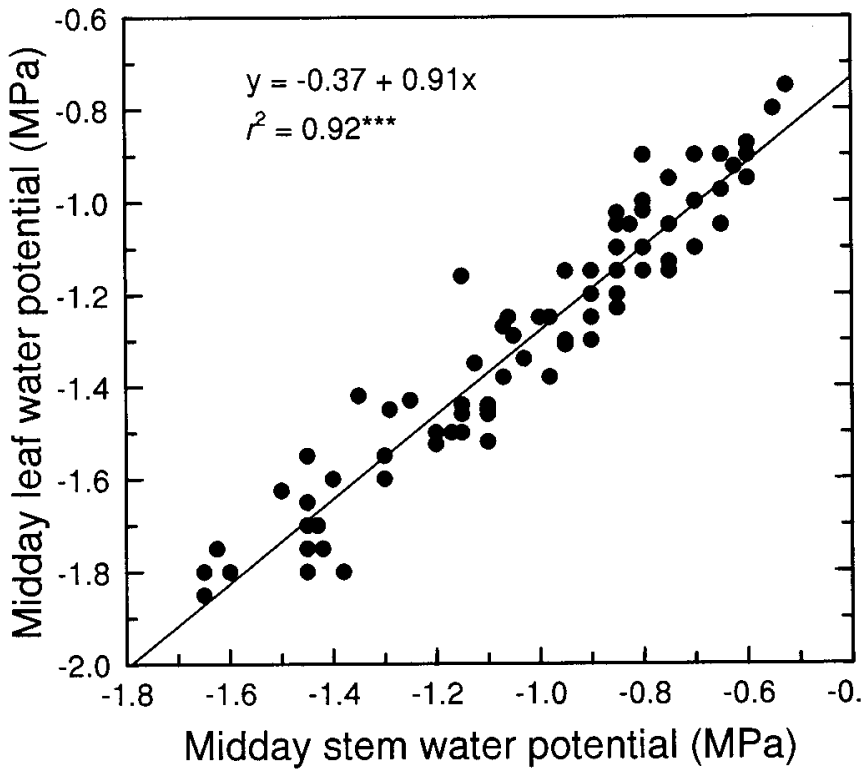

Fig. 3. Relationship between midday leaf water potential and midday stem water potential of 'Chardonnay' and 'Cabernet Sauvignon' grapevines. Each value is an individual leaf replicate. The coefficient of determination for a linear regression of the data using treatment means (such as used in Figs. 1 and 2) equals 0.96 . The slopes and intercepts for the three different measurement dates were not significantly different. ${ }^{* * *}$ Significant at $P<0.001$.

in terms of $\mathrm{H}_{2} \mathrm{O}$ for an individual leaf measured at either location were 440 and $70 \mathrm{mmol} \cdot \mathrm{m}^{-2} \cdot \mathrm{s}^{-1}$, respectively. All three measurements of vine water status were significantly correlated with A and $\mathrm{g}_{\mathrm{s}}$ (Table 3 ). Predawn leaf water potential was more highly correlated with $A$ and $g_{s}$ than either midday measurements of vine water status. Lastly, all three measures of vine $\Psi$ determined on 24 Aug. were linearly correlated $\left(r^{2}\right.$ values in excess of 0.93$)$ with berry weight and vine yield at the Carneros location when measured on 4 and 6 Oct., respectively (data not presented).

Mean $\left( \pm\right.$ SE) midday $\Psi_{1}$ of the 'Merlot' vines irrigated at $120 \%$ of estimated $\mathrm{ET}_{\mathrm{c}}$ were $-0.93 \pm 0.01,-1.04 \pm 0.03$, and $-1.21 \pm 0.01$ $\mathrm{MPa}$ for leaves covered with a plastic bag before excision, covered with a plastic bag just after excision, and leaves not covered with plastic at any time, respectively. Mean midday $\Psi_{1}$ of vines irrigated at $40 \%$ of estimated $\mathrm{ET}_{\mathrm{c}}$ were $-1.33 \pm 0.01,-1.45$ \pm 0.01 , and $-1.52 \pm 0.02 \mathrm{MPa}$ for the above mentioned treatments, respectively. Differences in $\Psi_{1}$ between leaves covered with the bag before excision and those not covered at all were greater for the vines irrigated at $120 \%$ of $\mathrm{ET}_{\mathrm{c}}$ compared to those at $40 \%$.

Table 3. Regression equations of $\mathrm{A}$ and $\mathrm{g}_{\mathrm{s}}$ as a function of the method of measuring vine water status and the coefficients of determinations and their significance level. Net $\mathrm{CO}_{2}$ assimilation rate (A) was expressed in terms of $\mathrm{CO}_{2}$ as $\mathrm{mmol} \cdot \mathrm{m}^{-2} \cdot \mathrm{s}^{-1}$, stomatal conductance to water vapor $\left(\mathrm{g}_{\mathrm{s}}\right)$ was expressed in terms of $\mathrm{H}_{2} \mathrm{O}$ as $\mathrm{mmol} \cdot \mathrm{m}^{-2} \cdot \mathrm{s}^{-1}$ and water potential was expressed as MPa.

\begin{tabular}{llll}
\hline \hline$\Psi$ & Gas & & \\
$\begin{array}{l}\text { measurement } \\
(\mathrm{x})\end{array}$ & $\begin{array}{l}\text { exchange } \\
(\mathrm{y})\end{array}$ & Regression & $r^{2}$ \\
\hline$\Psi_{\mathrm{PD}}$ & $\mathrm{A}$ & $\mathrm{y}=11.8+14.9 \mathrm{x}$ & $0.67^{* *}$ \\
& $\mathrm{~g}_{\mathrm{s}}$ & $\mathrm{y}=298+325 \mathrm{x}$ & $0.69^{* *}$ \\
$\Psi_{1}$ & $\mathrm{~A}$ & $\mathrm{y}=24.3+13.4 \mathrm{x}$ & $0.50^{*}$ \\
& $\mathrm{~g}_{\mathrm{s}}$ & $\mathrm{y}=600+314 \mathrm{x}$ & $0.58^{*}$ \\
$\Psi_{\text {stem }}$ & $\mathrm{A}$ & $\mathrm{y}=19.3+12.4 \mathrm{x}$ & $0.46^{*}$ \\
& $\mathrm{~g}_{\mathrm{s}}$ & $\mathrm{y}=485+293 \mathrm{x}$ & $0.54^{*}$ \\
\hline
\end{tabular}

${ }^{* *}$ Significant at $P<0.05$ or 0.01 , respectively. 


\section{Discussion}

The combination of irrigation treatments and evaporative demand resulted in large differences in various measures of leaf water potential and gas exchange parameters in this study. Vines that had been irrigated the previous day, depending upon the amount of water applied, had high values of $\Psi_{\mathrm{PD}}, \Psi_{1}$, and $\Psi_{\text {stem }}$ and high rates of $\mathrm{A}$ and $\mathrm{g}_{\mathrm{s}}$. Conversely, nonirrigated vines or vines which had not been irrigated due to an irrigation pump malfunction had low values. The mean $\mathrm{Y}_{\mathrm{PD}}$ values of vines irrigated at $100 \%$ of $\mathrm{ET}_{\mathrm{c}}$ (i.e., -0.02 to $-0.1 \mathrm{MPa}$ ) the day before measurements were taken was much higher than those of Correia et al., (1995) for well watered vines $\left(\Psi_{\mathrm{PD}}=-0.38 \mathrm{MPa}\right.$ ) but similar to that reported by Rodrigues et al. (1993). In addition, $\Psi_{\mathrm{PD}}$ of vines in a 'wet site' vineyard had lower values (Winkel and Rambal, 1993) than $\Psi_{\mathrm{PD}}$ reported herein. However, the lowest $\Psi_{\mathrm{PD}}$ recorded in this study, $-0.8 \mathrm{MPa}$, was much higher than the stressed vine's $\Psi_{\mathrm{PD}}(-1.13 \mathrm{MPa})$ in the study by Rodrigues et al. (1993) using potted vines.

Vines that received quantities of applied water at $100 \%$ of estimated $\mathrm{ET}_{\mathrm{c}}$ in this study had midday $\Psi_{1}$ values generally no lower than -1.0 MPa. This value is similar to the minimum midday $\Psi_{1}$ of 'Thompson Seedless' grapevines irrigated at full $\mathrm{ET}_{\mathrm{c}}$ (Grimes and Williams, 1990; Williams, 2000; Williams et al., 1994). It is much higher than the midday $\Psi_{1}$ reported for 'Sauvignon blanc' vines growing under nonlimiting soil water availability conditions with daily irrigation (Naor et al., 1997) or for continuously irrigated V. labruscana (Naor and Wample, 1994). It is also higher than the midday $\Psi_{1}$ reported for a wet site in France (Winkel and Rambal, 1993). The minimum $\Psi_{1}$ values reported herein at midday are similar to minimum $\Psi_{1}$ values measured on field grown grapevines (Chaves and Rodriques, 1987; Schultz, 1996; Winkel and Rambal, 1993). Lastly, extremes of midday $\mathrm{Y}_{\text {stem }}$ measured in this study were similar in range to that reported on V. labruscana (Naor and Wample, 1994; Liu et al., 1978) and $V$. vinifera 'Colombard' (Stevens et al., 1995).

The present investigation is the first study the authors are aware of in which the three 'standard' methods of estimating grapevine water status in the field (i.e., $\Psi_{\mathrm{PD}}, \Psi_{1}$, and $\Psi_{\text {stem }}$ ) had been measured and compared specifically with one another. The highest correlation of the comparisons among $\Psi_{\mathrm{PD}}, \Psi_{1}$, and $\Psi_{\text {stem }}$ was that between midday $\Psi_{1}$ and $\Psi_{\text {stem }}$. This was despite the fact that the correlation was made on individual leaf replicates between these two as opposed to treatment means when $\Psi_{1}$ and $\Psi_{\text {stem }}$ were correlated with $\Psi_{\mathrm{PD}}$. The high correlation between the individual leaf, midday measurements of $\Psi$ may have been due to the fact that the measurements were made simultaneously from leaves on the same vine. van Zyl (1987) found a $r^{2}$ of 0.66 when $\Psi_{1}$ was correlated with $\Psi_{\mathrm{PD}}$. An analysis by the authors of this paper of the $\Psi_{\mathrm{PD}}$ and daily minimum $\Psi_{1}$ reported by Winkel and Rambal (1993) indicate that the two were linearly correlated $\left(r^{2}\right.$ $\approx 0.5$ ). Stevens et al. (1995) found that diurnal measurements of $\Psi_{1}$ and $Y_{\text {stem }}$ of 'Colombard' on 'Ramsey' rootstock were highly correlated with one another. When the diurnal $\Psi_{1}$ and $\Psi_{\text {stem }}$ data in Fig. 4 of Liu et al. (1978) are linearly correlated with each another (performed by the authors of this paper), one obtains an $r^{2}>0.95$. The above would indicate that either measurement of midday $\Psi$ would give a good estimate of the water status of grapevines. This may not hold true for other plant species as Naor et al. (1995) found the correlation between $\Psi_{1}$ and $\Psi_{\text {stem }}$ of apple to have a $r^{2}$ of just 0.35 . However, it would appear that the $\Psi_{\text {stem }}$ and $\Psi_{1}$ of peach [Prunus persica (L.) Batsch (Peach group)] trees presented in Fig. 5 of Seles and Berger (1990), would be highly correlated with one another.

Predawn leaf water potential has been used in many grape studies as the standard to which other measures of the vine's water status are compared (Correia et al., 1995; Rodrigues et al., 1993; Schultz, 1996; van Zyl, 1987; Winkel and Rambal, 1993). It is assumed that the vine is in equilibrium with water potential of the soil at that time (Winkel and Rambal, 1993). The relationships between $\Psi_{\mathrm{PD}}$ of 'Chardonnay' and SWC found in this study and a similar comparison by van Zyl (1987) ( $\Psi_{\mathrm{PD}}$ vs. SWC in that study resulted in a $r^{2}$ of 0.89 ), indicates that measurement of $\Psi_{\mathrm{PD}}$ on grapevines may provide a good estimate of the soil moisture status within a vineyard. It has also been demonstrated, though, that season long measurements of midday $\Psi_{1}$ on 'Chardonnay' (same vines as used in this study) (Williams, 1996) and 'Thompson Seedless' (Williams et al., 1994) are highly correlated $\left(r^{2}=\right.$ 0.82 and 0.67 , respectively) with the seasonal change in SWC of treatments irrigated with differing applied amounts of water. That data, along with the data in Table 2 would indicate midday $\Psi_{1}$ also is reflective of the amount of water in the soil profile under the environmental and soil conditions of this study.

The suggestion that $\Psi_{\text {stem }}$ and $\Psi_{\mathrm{PD}}$ are better indicators than $\Psi_{1}$ of grapevine water status is based on correlations of those $\Psi$ measurements with leaf gas exchange (Chone et al., 2001; Naor, 1998) or the convergence of $\Psi_{1}$ later in the day among treatments that are assumed to have different water statuses (Correia et al., 1995; Naor and Wample, 1994). Naor (1998) found a better linear relationship between $Y_{\text {stem }}$ and $g_{s}$ than $\Psi_{1}$ and $g_{s}$ for measurements made between 0900 and 1400 HR on 'Sauvignon blanc' grapevines. However, Naor et al. (1994) reported previously that $g_{s}$ was highly correlated with $\Psi_{1}$ of 'Sauvignon blanc' grapevines. In addition, Naor et al. (1997) has also reported that the relationship between $g_{\mathrm{s}}$ and $\Psi_{\text {stem }}$ of 'Sauvignon blanc' was curvilinear, not linear. The differences noted above for 'Sauvignon blanc,' would indicate that correlation of vine water status (either $\Psi_{\text {stem }}$ or $\Psi_{1}$ ) with only a single criterion, such as $\mathrm{g}_{\mathrm{s}}$, can differ from study to study. In the present study, more than one parameter of vine water status was measured, for two different cultivars, on three different dates, in addition to the measurement of soil water content and applied water amounts.

Correia et al. (1995) found differences in $\Psi_{\mathrm{PD}}$ between well watered and stressed treatments but no differences in $\Psi_{1}$ later in the day, at 1000 and 1600 HR. However, it has been found that in some cases $\Psi_{\mathrm{PD}}$ of different plant species will come into equilibrium with the wettest portion of the soil in the plant's root zone (Ameglio et al., 1999; Tardieu and Katerji, 1991). Therefore, the soil moisture a plant responds to at midday may differ from that at predawn due to the flux of water occurring while the plant is actively transpiring (Jensen et al., 1989; Stevens et al., 1995). Thus, differences observed at predawn may not necessarily reflect the water status of the plant later in the day, such as observed in the present study (Table 1,110R rootstock data on 21 Sept.) and the data of Chone et al. (2001).

Other studies which have concluded that either $\Psi_{\mathrm{PD}}$ or $\Psi_{\text {stem }}$ were better measures of plant water status did not expressly state in the materials and methods that leaves were covered with a plastic bag before leaf excision for measurement of $\Psi_{1}$ (Chone et al, 2001; Garnier and Berger, 1985; van Zyl, 1987) or covered the leaf only after excision (Naor, 1998). There is a rapid loss of water from actively transpiring leaves within a few seconds of excision such that the $\Psi_{1}$ of bagged leaves is higher than that of nonbagged leaves (Turner and Long, 1980). This was demonstrated in the 
present study using 'Merlot' grapevines grown in the San Joaquin Valley. It was also demonstrated that leaves bagged just subsequent to leaf excision also had more negative $\Psi_{1}$ than those that were bagged before excision. Therefore, the method used in measuring midday $\Psi_{1}$ could influence subsequent interpretation of the data regarding its correlation with other means of determining plant water status.

One last factor that may have improved the reliability of using $\Psi_{1}$ to estimate vine water status in this study was the limitation placed upon time (1230 to 1330 HR Pacific Daylight Time) when midday measurements were taken. It is during this time that maximum diurnal water use (Williams, 2000) or canopy conductance (Williams, 1999) has been measured on nonwater-stressed 'Thompson Seedless' grapevines irrigated at $100 \%$ of ET with the use of a weighing lysimeter. Canopy conductance of 'Thompson Seedless' grapevines that had not been irrigated for $15 \mathrm{~d}$ is greatest early in the morning but maximum diurnal water use also occurs around solar noon (Williams, 1999). Time periods for measurements of midday $\Psi$ have been from 1100 to $1400 \mathrm{HR}$ for grape (Chone et al., 2001) and 1200 to 1500 HR for trees (McCutchan and Shackel, 1992). Leaf water potential of 'Thompson Seedless' grapevines can vary considerably between 1100 and $1500 \mathrm{HR}$ during the day, possibly due to changes in vapor pressure deficit (VPD) and ambient temperature (Williams et al., 1994) and therefore it is expected that $\Psi_{1}$ of other $V$. vinifera cultivars and species would be the same. Thus, midday $\Psi_{1}$ values would have a larger deviation around the mean, resulting in fewer significant differences, as found by McCutchan and Shackel (1992) and Chone et al. (2001), than perhaps measurements taken only $0.5 \mathrm{~h}$ on either side of solar noon.

All three methods of estimating vine water status used in this study were similarly correlated with SWC, applied amounts of water and with one another, with only a few exceptions. In addition, they were significantly correlated with midday measurements of leaf gas exchange. Therefore, the criterion that estimates of plant water status should reflect the availability of soil moisture and/or applied water amounts or measures of shortor medium-term plant stress responses (Higgs and Jones, 1990; Shackel et al., 1997) and growth (Naor, et al. 1995), were met for all measures of $\Psi$ under the conditions of this study.

Currently in California, some of the larger wineries and crop consultants are using measurement of vine water status as an aid in vineyard irrigation management decisions. They are using leaf water potential to determine when to start irrigating at the beginning of the season and sometimes for the determination of the interval between irrigation events. Based upon the data collected in this study, critical values of $\Psi_{\mathrm{PD}}, \Psi_{1}$, or $\Psi_{\text {stem }}$ could be established and utilized to assist in making such decisions. However, from a practical standpoint, measurement of midday $\Psi_{1}$ would be most convenient. One would not have be in the vineyard before sunrise to measure $\Psi_{\mathrm{PD}}$ nor arrive in the vineyard $90 \mathrm{~min}$ before taking midday $\Psi_{\text {stem }}$ readings in order to bag the leaves in plastic and cover with aluminum foil. However, the time frame used to measure midday water potentials in this study was restricted to $0.5 \mathrm{~h}$ on either side of solar noon. Such a restriction would limit the acreage or number of vineyards one could measure with limited resources on a daily basis. The extension in the measurement of $\Psi_{1}$ before or after the 1230 to $1330 \mathrm{HR}$ time frame used herein to a commercial situation could be accomplished with its calibration to environmental variables such as ambient temperature and VPD as done for cotton (Gossypium hirsutum L.) (Grimes et al., 1987) and VPD as done for deciduous fruit trees
(Shackel et al., 1997). Lastly, it has been demonstrated that the individual making measurements of plant water status is a significant source of variation, even for stem water potential (Goldhamer and Fereres, 2001). Therefore, it is imperative that technicians be well trained in the use of the pressure chamber and the choice of leaves to sample.

\section{Literature Cited}

Ameglio, T., P. Archer, M. Cohen, C. Valacogne, F. Daudet, S. Dayau, and P. Cruiziat. 1999. Significance and limits in the use of predawn leaf water potential for tree irrigation. Plant Soil 207:155-167.

Begg, J.E. and N.C. Turner. 1970. Water potential gradients in field tobacco. Plant Physiol. 46:343-346.

Chaves, M.M. and M.L. Rodrigues. 1987. Photosynthesis and water relations of grapevines in Portugal - Response to environmental factors, p. 381-390. In: J.D. Tenhunen, F.M. Catarino, O.L. Lange, and W.C. Oechel (eds.). Plant response to stress. NATO ASI Series. vol. G15. Springer-Verlag, Berlin.

Chone, X, C. Van Leeuwen, D. Dubourdieu, and J.P. Gaudillere. 2001. Stem water potential is a sensitive indicator for grapevine water status. Ann. Bot. 87:477-483.

Correia, M.J., J.S. Pereira, M.M. Chaves, M.L. Rodrigues, and C.A. Pacheco. 1995. ABA xylem concentrations determine maximum daily leaf conductance of field-grown Vitis vinifera L. plants. Plant Cell Environ. 18:511-521.

Garnier, E. and A. Berger. 1985. Testing water potential in peach trees as an indicator of water stress. J. Hort. Sci. 60:47-56.

Garnier, E. and A. Berger. 1987. The influence of drought on stomatal conductance and water potential of peach trees growing in the field. Scientia Hort. 32:249-263.

Goldhamer, D.A. and E. Fereres. 2001. Simplified tree water status measurements can aid almond irrigation. Calif. Agr. 55:32-37.

Greenspan, M.D., H.R. Schultz, and M.A. Matthews. 1996. Field evaluation of water transport in grape berries during water deficits. Physiol. Plant. 97:55-62.

Grimes, D.W. and L.E. Williams. 1990. Irrigation effects on plant water relations and productivity of 'Thompson Seedless' grapevines. Crop Sci. 30:255-260.

Grimes, D.W., H. Yamada, and S.W.Hughes. 1987. Climate-normalized cotton leaf water potentials for irrigation scheduling. Agr. Water Mgt. 12:293-304.

Higgs, K.H. and H.G. Jones. 1990. Response of apple rootstocks to irrigation in south-east England. J. Hort. Sci. 65:129-141.

Jensen, C.R., I.E. Henson, and N.C. Turner. 1989. Leaf gas exchange and water relations of lupins and wheat. II. Root and shoot water relations of lupin during drought-induced stomatal closure. Austral. J. Plant Physiol. 16:415-428.

Jones, H.G. 1990. Physiological aspects of the control of water status in horticultural crops. HortScience 25:19-26.

Koide, R.T., R.H. Robichaux, S.R. Morse, and C.M. Smith. 1989. Plant water status, hydraulic resistance and capacitance, p. 161-183. In: R.W. Pearcy, J.R. Ehleringer, H.A. Mooney, and P.W. Rundel (eds.). Plant physiological ecology: Field methods and instrumentation. Chapman and Hall, New York.

Lampinen, B.D., K.A. Shackel, S.M. Southwick, B. Olson, J.T. Yeager, and D. Goldhamer. 1995. Sensitivity of yield and fruit quality of French prune to water deprivation at different fruit growth stages. J. Amer. Soc. Hort. Sci. 120:139-147.

Liu, W.T., W. Wenkert, L.H. Allen, and E.R. Lemon. 1978. Soil-plant water relations in a New York vineyard: Resistance to water movement. J. Amer. Soc. Hort. Sci. 103:226-230.

McCutchan, H. and K.A. Schakel. 1992. Stem-water potential as a sensitive indicator of water stress in prune trees (Prunus domestica $\mathrm{L}$. cv. French). J. Amer. Soc. Hort. Sci. 117:607-611.

Naor, A. 1998. Relations between leaf and stem water potentials and stomatal conductance in three field-grown woody species. J. Hort. Sci. Biotechnol. 73:431-436. 
Naor, A., B. Bravdo, and J. Gelobter. 1994. Gas exchange and water relations in field-grown 'Sauvignon blanc' grapevines. Amer. J. Enol. Viticult. 45:423-428.

Naor, A., Y. Gal, and B. Bravdo. 1997. Crop load affects assimilation rate, stomatal conductance, stem water potential and water relations of field-grown 'Sauvignon blanc' grapevines. J. Expt. Bot. 48:16751680.

Naor, A., I. Klein, and I. Doron. 1995. Stem water potential and apple size. J. Amer. Soc. Hort. Sci. 120:577-582.

Naor, A. and R.L. Wample. 1994. Gas exchange and water relations of field-grown 'Concord' (Vitis labruscana Bailey) grapevines. Amer. J. Enol. Viticult. 45:333-337.

Olien, W.C. and A.N. Lakso. 1986. Effect of rootstock on apple (Malus domestica) tree water relations. Physiol. Plant. 67:421-430.

Padgett-Johnson, M., L.E. Williams, and M.A. Walker. 2000. The influence of Vitis riparia rootstock on water relations and gas exchange of Vitis vinifera cv. Carignane scion under non-irrigated conditions. Amer. J. Enol. Viticult. 51:137-143.

Rodrigues, M.L., M.M. Chaves, R. Wendler, M.M. David, W.P. Quick, R.C. Leegood, M. Stitt, and J.S. Pereira. 1993. Osmotic adjustment in water stressed grapevine leaves in relation to carbon assimilation. Austral. J. Plant Physiol. 20:309-321.

Scholander, P.F., H.J. Hammel, A. Bradstreet, and E.A. Hemmingsen. 1965. Sap pressure in vascular plants. Science 148:339-346.

Schultz, H.R. 1996. Water relations and photosynthetic responses of two grapevine cultivars of different geographical origin during water stress. Proc. Workshop Strategies to Optimize Wine Grape Quality. Acta Hort. 427:251-266.

Schultz, H.R. and M.A. Matthews. 1988. Vegetative growth distribution during water deficits in Vitis vinifera L. Austral. J. Plant Physiol. 15:641-656.

Schultz, H.R. and M.A. Matthews. 1993. Growth, osmotic adjustment and cell-wall mechanics of expanding grape leaves during water deficits. Crop Sci. 33:287-294.

Selles, G. and A. Berger. 1990. Physiological indicators of plant water status as criteria for irrigation scheduling. Acta. Hort. 278:87-100.

Shackel, K.A., H. Ahmadi, W. Biasi, R. Buchner, D. Goldhammer, S Gurusinghe, J. Hasey, D. Kester, B. Krueger, G. McGourty, W. Micke, E. Mitcham, B. Olson, K. Pelletrau, H. Phillips, D. Ramos, L. Schwankl,
S. Sibbett, R. Snyder, S. Southwick, M. Stevenson, M. Thorpe, S. Weinbaum, and J. Yeager. 1997. Plant water status as an index of irrigation need in deciduous fruit trees. HortTechnology 7:23-29.

Smart, R.E. and B.G. Coombe. 1983. Water relations of grapevines, p. 137-196. In: T.T. Kozlowski (ed.). Water deficit and plant growth. vol. 7. Academic Press, New York.

Stevens, R.M., G. Harvey, and D. Aspinall. 1995. Grapevine growth of shoots and fruit linearly correlate with water stress indices based on root-weighted soil matric potential. Austral. J. Grape Wine Res. 1:5866.

Tardieu, F. and N. Katerji. 1991. Plant response to the soil water reserve: Consequences of the root system environment. Irr. Sci. 12:145-152.

Turner, N.C. and M.J. Long. 1980. Errors arising from rapid water loss in the measurement of leaf water potential by the pressure chamber technique. Austral. J. Plant Physiol. 7:527-537.

van Zyl, J.L. 1987. Diurnal variation in grapevine water stress as a function of changing soil water status and meteorological conditions. S. Afr. J. Enol. Viticult. 8:45-52.

Williams, L.E. 1996. Effects of soil water content and environmental conditions on vine water status and gas exchange of Vitis vinifera L.cv. 'Chardonnay'. Proc. ${ }^{\text {st }}$ Intl. Colloque Les Terroirs Viticoles, p. 161163, 17-18 July 1996, Angers, France.

Williams, L.E. 1999. Water use of 'Thompson Seedless' grapevines measured with a weighing lysimeter during a late season dry down period. Proc. $1^{\text {st }}$ ISHS Workshop on Water Relations of Grapevines. Acta. Hort. 493:161-167.

Williams, L.E. 2000. Grapevine water relations, p. 121-126. In: L.P. Christensen (ed.). Raisin production manual. Univ. Calif. Div. Agr. Natural Resources Publications, Oakland.

Williams, L.E., N.K. Dokoozlian, and R.L. Wample. 1994. Grape, p. 83133. In: B. Shaffer and P.C. Anderson (eds.). Handbook of environmental physiology of fruit crops. vol. 1. Temperate crops. CRC Press, Orlando, Fla.

Winkel, T. and S. Rambal. 1990. Stomatal conductance of some grapevines in the field under a Mediterranean environment. Agr. Forest Meterol. 51:107-121.

Winkel, T. and S. Rambal. 1993. Influence of water stress on grapevines growing in the field: From leaf to whole-plant response. Austral. J. Plant Physiol. 20:143-157. 